\title{
AN ANALYSIS OF INVENTORY INVESTMENT IN SOUTH
}

\section{AFRICA}

\author{
H. Smith, J.N. Blignaut and J.H. van Heerden*
}

\begin{abstract}
This paper describes the evolution of inventory investment in South Africa over the past two decades, and identifies the factors influencing inventory investment over this period. An econometric model of inventory investment in South Africa, based on the production smoothing approach, is constructed. The results of the model indicate that actual sales, production, unfilled orders, price levels, interest rates and expected sales have an influence on the evolution of inventory investment. These variables are directly or indirectly influenced by macroeconomic policy decisions and through their influence on inventory investment they also influence changes in gross domestic product. Therefore, prior information on the factors that influence inventory investment contributes to explaining changes in gross domestic product and may help to prepare more accurate short-term forecasts of overall economic activity.
\end{abstract}

\section{INTRODUCTION}

Production and sales are economic processes that continuously adjust to changes in demand and supply conditions, but it seldom happens that changes in the one would exactly meet changes in the other. The difference between demand and supply is reflected by the change in inventories. An increase in the level of inventories implies that a part of production was not sold. Conversely, sales exceed production when inventory levels decrease. Conventionally, inventory changes occur either as the outcome of planned or predetermined action among producers and consumers, or are the net result of exogenous shocks influencing the behaviour of producers and consumers (Kahn \& McConnell 2002).

Inventory investment contributes significantly to the changes in gross domestic expenditure and gross domestic product, not through its size, but as a result of its rate of change. Analysing the factors that influence investment in inventories should lead to a better understanding of the dynamics of the economic system.

The purpose of this paper is to describe the evolution of inventory investment in the South African economy over the past two decades, and to identify the factors that had an influence on inventory investment over this period. Following this introduction, the composition, structure and cyclical nature of inventory investment in South Africa is discussed, followed by the methodology for estimating inventory investment at the

* Herman Smith is attached to the National Accounts Section at the United Nations (New York), but was at the time of writing working at the South African Reserve Bank. James Blignaut and Jan van Heerden are attached to the Department of Economics, University of Pretoria. Views expressed are those of the authors and do not necessarily reflect those of any institution they may be involved with. 
macroeconomic level. This is followed by a short review of the factors determining inventory investment based on international evidence. An attempt is then made to quantifying behavioural relationships between inventory investment and potential explanatory variables while we also analyse the contribution of inventory investment to changes in gross domestic product. The final section contains some concluding comments.

\section{ESTIMATING AGGREGATE INVENTORY INVESTMENT}

Inventory investment in South Africa is estimated by the South African Reserve Bank as part of gross capital formation, which is an important component of aggregate gross domestic expenditure. For national accounts purposes, the change in inventories during any period, for example a quarter, is calculated as the physical change in inventories from the end of the preceding period to the end of the current period, valued at market prices prevailing during that period (Shrestha \& Fassler 2003:6).

Information on the physical change in inventories is, however, seldom available. To obtain the closest approximation of inventory investment, the end-of-period inventories at constant prices is calculated by deflating the end-of-period book value of inventories at current values by appropriate price indices. These price indices are essentially subcomponents of the production price index. The change in inventories at constant prices is then determined as the first difference in the value of the end-ofperiod inventories at constant prices (Smith \& Van Den Heever 1995:33 and Shrestha \& Fassler 2003:17).

The change in inventories at current prices is calculated by multiplying the change in inventories at constant prices by the average value of the price index in the relevant period. Algebraically the change in inventories can be summarised as follows:

$$
\text { P t } \quad \mathrm{Pt}-1 y
$$

where:

AI = change in inventories, $\mathrm{I}_{\mathrm{t}}=$ end of period inventories,

$\mathrm{P}_{\mathrm{t}}=$ production price index, and

$\mathrm{P}=$ average price index in period $t$, calculated as $1 / 2\left(\mathrm{P}_{\mathrm{t}}+\mathrm{P}_{\mathrm{t}}-1\right)$

\section{THE STRUCTURE AND CYCLICAL CHANGES OF INVENTORIES IN SOUTH AFRICA}

Industrial and commercial inventories are the most important component of inventory investment in South Africa and they dominate the long-term movements in inventory investment. There is generally a positive correlation between the inventory investment cycle and the business cycle. Inventories increase during upward phases of the business cycle and decrease during downward phases.

However, the turning points of the inventory cycle and the business cycle do not coincide, which can be attributed to the different lengths of the cycles and circumstances 
openUP (August 2007)

Table 1. The variance of production and sales in the period 1975 to 2002

\begin{tabular}{lcllll}
\hline & $\begin{array}{c}\text { Variance of } \\
\text { sales (S) } \\
\text { R millions }\end{array}$ & $\begin{array}{l}\text { Variance } \\
\text { of } \\
\text { R millions }\end{array}$ & $\begin{array}{l}\text { Produc- } \\
\text { tion (Q) }\end{array}$ & Q/S & $\begin{array}{l}\text { Correlation } \\
\text { between inventory } \\
\text { investment and } \\
\text { sales }\end{array}$ \\
Manufacturing & 5252 & 5164 & & 0,983 & $-0,2220$ \\
Trade & 1702 & 1216 & 0,715 & $-0,6313$ \\
$\quad$ Wholesale & 1260 & 730 & 0,580 & $-0,7769$ \\
Retail trade & 763 & 431 & 0,565 & $-0,8264$ \\
Motor trade & 540 & 232 & 0,429 & $-0,8746$ \\
Total & 6243 & 6000 & & 0,961 & $-0,2469$ \\
\hline
\end{tabular}

Source: South African Reserve Bank

particular to the inventory and business cycles. Since the middle of the 1970s the turning points of the inventory investment cycle in South Africa preceded the turning points of the business cycle in the upward phases on average by about $3 \frac{1}{2}$ months and in the downward phases on average by about $5 \frac{1}{2}$ months. During the period 1960 to 1975, the turning points of the inventory cycle lagged or coincided with the turning points of the business cycle. This change in inventory behaviour can probably be ascribed to improved inventory management techniques, making it possible for manufacturers and traders to adjust timely to expected changes in demand (Smith 2004:128 and Kahn \& McConnell 2002).

An analysis of inventory investment in South Africa and macroeconomic variables such as gross domestic product, total sales, new orders, unfilled orders and indicators that represent the cost of production, show a clear statistical relationship. Smaller increases in unit labour cost and production prices, lower levels of interest rates and the real effective exchange rates contribute to decisions to increase the level of inventories (Smith 2004:137).

The importance of inventory investment in the economy can be assessed by comparing the ratio of domestic final demand and inventory investment to the level of gross domestic product, and the contributions of the change in domestic final demand and the change in inventory investment to the growth in gross domestic product.

The average ratio of inventory investment to the level of gross domestic product in the period 1975 to 2002 was 1,2 per cent compared to a ratio of 96,2 per cent in the case of domestic final demand. Although the share of inventory investment in the expenditure on gross domestic product is small, it contributes materially to changes in gross domestic product over the course of the business cycle.

During the downswing phases of the business cycle inventory investment subtracted on average 2,9 percentage points per year from the change in gross domestic product. This negative contribution exceeded the positive contribution of 2,2 percentage points by domestic final demand. During the upward phases of the business cycle, inventory investment added 3,0 percentage points per year to the increase in gross domestic product, compared to the contribution of 12,4 percentage points per year by domestic final demand (South African Reserve Bank, Quarterly Bulletin, various issues).

On average, the changes in inventories over the full business cycle made limited contributions to the changes in gross domestic product, but contributed significantly to the cyclical movements of gross domestic product during the upward and downward phases of the business cycle.

In Table 1 the variance of production and sales of the industrial and commerce sectors since 1975 are compared in the first three columns. In the fourth column the correlation between inventory investment and sales is depicted. Column three shows that the 
Table 2. The level of inventories and the variance of inventory investment*

\begin{tabular}{|c|c|c|c|c|}
\hline & $\begin{array}{l}\text { Average } \\
\text { level in } \\
2002\end{array}$ & $\begin{array}{l}\text { Percentage } \\
\text { of the total }\end{array}$ & $\begin{array}{l}\text { The variance of } \\
\text { Inventory Invest- } \\
\text { ment for the period } \\
1975-2002\end{array}$ & $\begin{array}{l}\text { Coeffi- } \\
\text { cient of } \\
\text { variation }\end{array}$ \\
\hline & $\mathbf{R}$ millions & $\%$ & R Millions & \\
\hline Manıfacturing & 586.99 & 60.4 & 1086 & 16. $?$ \\
\hline Trade & .384 .34 & 39.6 & 1174 & 21.7 \\
\hline Wholesale trade & 17217 & 17.7 & 1071 & 880 \\
\hline Retail trade & 1.560 .9 & 16.1 & 649 & 2.3 .4 \\
\hline Motor trade & 5609 & 58 & 470 & 3) 4 \\
\hline Total industrv and & 97133 & 100 & & 14.3 \\
\hline
\end{tabular}

Source: South African Reserve Bank

* At constant 1995 prices

variance in production is smaller than the variance in sales. This can probably be ascribed to a sharp increase in the marginal cost of production. In addition, according to column four, the correlation between inventory investment and sales is negative. These results are in contrast to those from the studies of Blinder and Maccini (1991) for the USA and Flood and Lowe (1995) for Australia. Flood and Lowe (1995:29) indicated that the variance in production would be more than the variance in sales when the marginal cost of production does not rise sharply.

The variance of sales exceeding the variance of production and the negative correlation between inventory investment and sales, are supported by the theory of the productionsmoothing hypothesis, which states that businesses hold inventories to smooth production in an environment of random demand changes and rising marginal cost of production. Fukuda and Teruyama (1988) found similar results for developing counties. According to them the ratio of the variance of production to the variance of sales for South Africa is 0,81 compared to the ratio of 0,96 found in this study. This characteristic in developing countries is probably the result of the influence of demand shocks on macroeconomic variables.

According to Blinder and Maccini (1991) retail trade inventories and raw materials in the manufacturing sector contribute most to the variance in total inventory investment, while inventories of finished goods in the manufacturing sector contribute least. Table 2 shows a similar pattern in the evolution of industrial and commercial inventory investment in South Africa. Unfortunately, data according to the type of inventories are not available for the manufacturing sector in South Africa.

The first two columns in Table 2 indicate the average level of inventories and the last two columns show the variance in inventory investment. The level of manufacturing inventories is higher than that of inventories in the trade sector, where the wholesale trade sector dominates. The combined industrial and commercial sectors consist of the subsectors manufacturing, wholesale trade, retail trade and motor trade.

Judging by the coefficient of variation, the variance of inventory investment in the trade sector exceeds that of the manufacturing sector and inventory changes in the wholesale trade sector are by far the most volatile component of inventories. The fact that the variance of inventory investment in the trade sector exceeds that of manufacturing can probably be attributed to the impact of imports on wholesale trade inventories. The bundling of imports can lead to a higher variance in the inventory investment of the wholesale trade sector. 
openUP (August 2007)

\section{A MODEL OF INVENTORY INVESTMENT IN SOUTH AFRICA}

Most of the applied research on inventories has used some or other form of the inventory model developed by Holt, Modigliani, Muth and Simon (1960). This model follows the production smoothing approach, and takes into account the cost of inventory shortages, unfilled orders and random changes in demand. It accepts that businesses hold inventories to smooth production in an environment of changing demand and rising marginal cost of production. However, the increase in the marginal cost of production is more relevant to manufacturers than traders. Consequently the bulk of applied research on inventories concentrated on manufacturing inventory behaviour.

The results of the models using the production-smoothing approach are mixed. The research of Guariglia and Schiantarelli (1998) in the UK, Blinder and Maccini (1991) and Milne (1994) in the USA and Flood \& Lowe (1993) in Australia have found that the variance of production exceeds the variance of sales, therefore rejecting the productionsmoothing hypothesis. Even when the models are expanded, to include variables such as cost shocks to accommodate for the fact that the variance of production exceeds the variance of sales, they do not perform well. In addition, the estimated coefficients of the inventory-adjustment model imply that the speed of adjustment of the gap between expected and actual inventories is too slow (Feldstein \& Auerbach 1976) and that inventories do not play a significant role in absorbing demand shocks (Blinder 1986).

Ramey \& West (1997), however, indicated a number of inconsistencies in the results of studies that they had analysed and attributed it to econometric problems such as sample size and estimation techniques. In contrast to the arguments of Blinder and Maccini (1991) that the production smoothing approach cannot be used, Ramey and West (1997:21) support its use to analyse the behaviour of aggregate inventories. Blanchard (1983) showed with an analysis of the production and retail sectors of the motor industry that an 'invisible hand' solves the optimisation problem in the motor industry.

Following Lovell (1961), the accelerator model of Smith and Van den Heever (1995) was expanded to construct a model of inventory investment in South Africa. The change in deflated book values after seasonal adjustment of industrial and commercial inventories at 1995 prices is the dependent variable. This type of inventories is the most important part of total inventories and has a significant impact on the evolution of total inventories.

Any dependent variable used to estimate inventory investment has shortcomings. One of these is the level of aggregation. Manufacturing inventories consist of inventories at different stages of production. Part of this is produced for inventories and others are produced on order. The inventories of the trade sector consist mostly of purchased inventories. It is reasonable to expect that changes in the aggregation of industrial and commercial inventories will have an influence on the regression coefficients.

Estimates of industrial and commercial inventories in South Africa are limited to quarterly values of total inventories in manufacturing, wholesale trade, retail trade and motor trade. In addition, the change in inventories is calculated from deflated book values. Taking into account the data limitations and by following Small (2000:17) a relatively simple inventory model could be used to analyse inventory behaviour in South Africa.

Inventory investment (DI) is modelled as a function of the extent to which the levels of actual inventories (I) and sales (S) deviate from expected inventories (I*) and sales ( $\left.\mathrm{S}^{*}\right)$. Inventory investment is then described by the following equation: 
$\Delta \mathrm{I}=\delta\left(\mathrm{I}_{\mathrm{t}}^{*}-\mathrm{I}_{\mathrm{t}-1}\right)+\lambda\left(\mathrm{S}_{\mathrm{t}}-\mathrm{S}_{\mathrm{t}}^{*}\right)$

where:

where:

$\delta=$ the rate of adjustment when the desired level of inventories deviates from the actual level,

$\lambda=$ the rate of adjustment of inventory investment when the expected level of sales deviates from the actual level,

$\Delta \mathrm{I}=$ the quarterly change in the seasonally adjusted real book value of industrial and commercial inventories at 1995 prices,

$\mathrm{I}_{\mathrm{t}}^{*}=$ the desired level of inventories at the end of period $\mathrm{t}$,

$I_{r-1}=$ the actual level of inventories at the end of period $t-1$, and

$\mathrm{S}_{\mathrm{t}}-\mathrm{S}_{\mathrm{t}}{ }^{*}=$ the unplanned change in inventories in period $\mathrm{t}$ as a result of the deviation between actual sales $\left(S_{t}\right)$ and expected sales $\left(S_{t}^{*}\right)$.

The desired level of inventories is dependent on the equilibrium ratio between inventories and sales, which can change over the course of the business cycle. This ratio is influenced by the relationship of sales to production, unfilled orders, price levels and interest rates. Unfilled orders reflect the imbalance between demand and production and the level of prices and interest rates represents the cost of holding inventories. Algebraically the desired level of inventories can be described as follows:

$\mathrm{I}_{\mathrm{t}}^{*}=\alpha \mathrm{S}_{\mathrm{t}-1}$

where

$\alpha=b_{0}+b_{1}\left(\frac{Q}{S}\right)_{t-1}+b_{2}\left(\frac{U}{S}\right)_{t-1}+b_{3}\left(\frac{P}{S}\right)_{t-1}+b_{4}\left(\frac{R}{S}\right)_{t-1}$

where:

$\mathrm{S}=$ real sales,

$\mathrm{Q}=$ real production by industry and commerce,

$\mathrm{U}=$ real unfilled orders,

$\mathrm{P}=$ the production price index,

$\mathrm{R}=$ the prime overdraft rate of banks.

For the purposes of estimating behavioural relationships quarterly seasonally adjusted data and real values at constant 1995 prices were used. Industrial and commercial production was approximated by the sum of real value added by manufacturing and commerce. Real sales were represented by gross domestic expenditure, excluding final consumption expenditure by general government, final consumption expenditure by households on services and industrial and commercial inventories, but including the exports of manufactured goods. The production price index was estimated as nominal industrial and commercial value added divided by real industrial and commercial value added.

Expected sales can be specified in numerous ways. Ramey and West (1997:30) stated that expected sales are a function of lagged sales and that the number of lags 
is determined by the data. F8Hewiff(Asgutcth2007d Van den Heever (1995:81), expected sales is described by the average sales of the past four quarters. Algebraically this can be formulated as follows:

$\mathrm{S}_{\mathrm{t}}^{*}=\frac{1}{4} \sum_{\mathrm{i}=1}^{4} \mathrm{~S}_{\mathrm{t}-\mathrm{i}}$

Substituting 3 in 2 ,

$I_{t}^{*}=b_{0} S_{t-1}+b_{1} Q_{t-1}+b_{2} U_{t-1}+b_{3} P_{t-1}+b_{4} R_{t-1}$

and substituting 4 and 5 in 1 ,

$$
\begin{aligned}
& \Delta \mathrm{I}_{\mathrm{t}}=\delta\left(\mathrm{b}_{0} \mathrm{~S}_{\mathrm{t}-1}+\mathrm{b}_{1} \mathrm{Q}_{\mathrm{t}-1}+\mathrm{b}_{2} \mathrm{U}_{\mathrm{t}-1}+\mathrm{b}_{3} \mathrm{P}_{\mathrm{t}-1}+\mathrm{b}_{4} \mathrm{R}_{\mathrm{t}-1}-\mathrm{I}_{\mathrm{t}-1}\right)+\lambda\left(\mathrm{S}_{\mathrm{t}}-\frac{1}{4} \sum_{\mathrm{j}=1}^{4} \mathrm{~S}_{\mathrm{t}-\mathrm{i}}\right) \\
& \Delta \mathrm{I}_{\mathrm{t}}=\delta \mathrm{b}_{0} \mathrm{~S}_{\mathrm{t}-1}+\delta \mathrm{b}_{1} \mathrm{Q}_{\mathrm{t}-1}+\delta \mathrm{b}_{2} \mathrm{U}_{\mathrm{t}-1}+\delta \mathrm{b}_{3} \mathrm{P}_{\mathrm{t}-1}+\delta \mathrm{b}_{4} \mathrm{R}_{\mathrm{t}-1}-\delta \mathrm{I}_{\mathrm{t}-1}+\lambda \mathrm{S}_{\mathrm{t}}-\lambda \frac{1}{4} \sum_{\mathrm{i} t-1}^{4} \mathrm{~S}_{\mathrm{t}-\mathrm{i}}
\end{aligned}
$$

Inventory investment is estimated with the two-step Engle-Granger procedure (Engle and Granger 1987) and the third-step procedure of Engle and Yoo (Engle and Yoo 1987). The equations are specified in $\log$ format so that the estimated coefficients reflect elasticities with respect to the explanatory variables.

The first step consists of the estimation of a long-run equation supported by relevant economic theory. On the basis of the close relationship between inventory investment, production and sales, the long-run equation is estimated with the level of inventories as the dependent variable and production and sales as the explanatory variables. The test results indicate stationarity of the residual from the equation; therefore the residual can be used in the error correction model. The results of the estimation, which provide a good fit of the level of inventories, are shown below.

$\mathrm{I}_{\mathrm{t}}=0.289613 \mathrm{Q}_{\mathrm{t}}+0.68872 \mathrm{~S}_{\mathrm{t}}$

$\mathrm{R}^{2}=0.8971$

Adjusted $\mathrm{R}^{2}=0.8955$

$\mathrm{DW}=0.935867$

ADF test on residual -4.775

Estimation period 1986:01-2002:04

Estimated with ordinary least squares; $t$ statistic in brackets under the estimated coefficients.

The second step is the estimation of the error correction model (ECM). The ECM is estimated using first differences in the log values of the variables. The dependent variable in the ECM is the change in inventories. The explanatory variables are the quarterly changes of production, unfilled orders, expected sales, interest rates and prices. The residual of the long-run equation (Resid01) was also used to explain the change in inventories in the ECM. 
Table 3. Diagnostic tests of the ECM

\begin{tabular}{llll}
\hline Test to determine & Test & Test statistic & Probability \\
Normality & Jarque Bera & 5.0563 & 0.0798 \\
Heteroscedasticity & ARCH & $\mathrm{nR}^{2}=1.0019$ & 0.9095 \\
& White & $\mathrm{nR}^{2}=4.2039$ & 0.9795 \\
Serial correlation & Breuch-Godfrey LM & $\mathrm{nR}^{2}=7.1838$ & 0.1265 \\
Stability & Ramsey reset, F-statistic & $\mathrm{LR}=0.9053$ & 0.6359 \\
& CUSUM and CUSUM & Provided stability & \\
\hline
\end{tabular}

The lag structure in equation 6 is only to simplify notation. Different data sets and estimation periods would have an influence on the lag structure. Following Ramey and West (1997) the information is allowed to find the final lag structure. After experimenting with various specifications, the following equation was estimated to describe inventory investment in South Africa:

$$
\begin{aligned}
& \begin{array}{l}
\Delta \mathrm{I}_{\mathrm{t}}= \\
-0.2015 \text { Resid01 } 1_{\mathrm{t}-1}+0.0804 \mathrm{U}_{\mathrm{t}-1}+0.5467 \frac{1}{4} \sum_{\mathrm{i}-1}^{4} \mathrm{~S}_{\mathrm{t}-\mathrm{i}}-0.0664 \mathrm{R}_{\mathrm{t}-2} \\
\quad(-4.0526) \quad(1.9021) \\
-0.2124 \mathrm{P}_{\mathrm{t}-3}+0.5272 \mathrm{Q}_{\mathrm{t}-2} \\
\quad(-2.3666) \quad(3.1414)
\end{array} \\
& \mathrm{R}^{2}=0.5050 \\
& \text { Adjusted } \mathrm{R}^{2}=0.4555 \\
& \text { DW }=1.5286 \\
& \text { Estimation period: } 1986: 01-2002: 04
\end{aligned}
$$

Estimated with ordinary least squares; t statistics in brackets under the estimated coefficients.

Table 3 shows various diagnostic tests of the ECM.

The influence of changes in supply conditions is represented by the production variable, $\mathrm{Q}$. The holding cost of inventories is captured by the price $(\mathrm{P})$ and interest rate $(\mathrm{R})$ variables, and changes in demand are captured by the changes in actual sales (S), expected sales ( $\left.\mathrm{S}^{*}\right)$ and unfilled orders (U) variables. An increase in demand would not immediately lead to a change in inventories; it would be represented by a change in unfilled orders and inventory investment would increase after a while.

The negative coefficients of the price and interest rate variables indicate that higher holding costs lead to lower inventory levels. Both variables have the correct sign according to prior reasoning and both parameters are estimated with a fairly high level of significance. Although international studies rarely found interest rates to have a significant influence on inventory investment, this study supports the results of Smith and Van den Heever (1995:82) who also found the interest rate to be significant for South African inventories.

The signs of the other estimated coefficients also conform to a priori reasoning and are estimated with high levels of significance. The $\mathrm{R}^{2}$ coefficient of determination seems low, but this is typically a consequence of using first differences as the dependent variable. In Fig. 1 the result of an in-sample simulation is shown. The actual values of inventory investment are well represented by the 


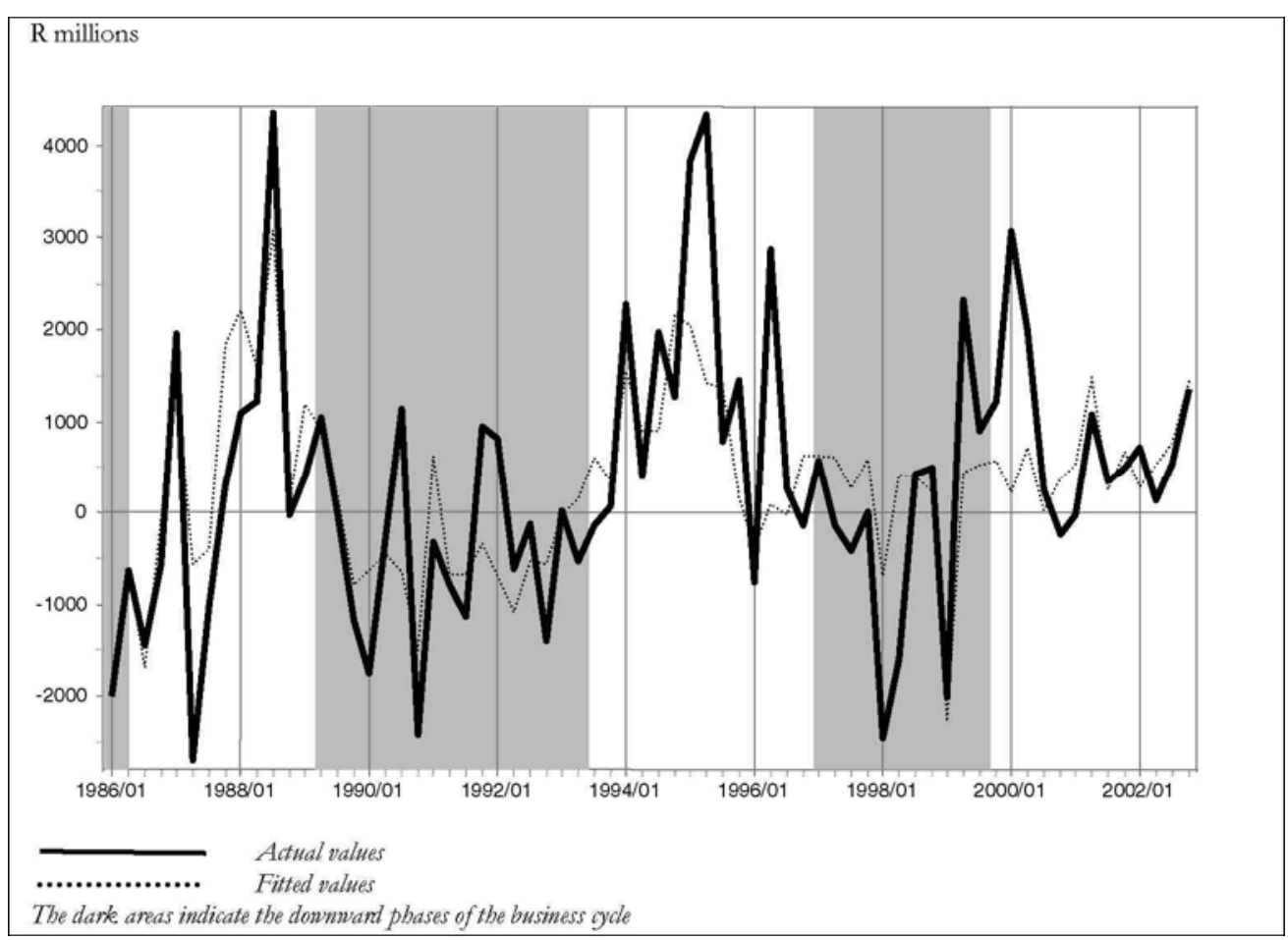

Figure 1. Real industrial and commercial inventory investment: Actual and fitted values

A further simulation was prepared by allowing the predetermined values of the level of inventories to be determined endogenously by the model. The simulated values of the level of inventories were used to calculate the accumulation of inventories. The result of this dynamic simulation is shown in Fig. 2.

The most significant deviations between the predicted and actual inventory investment are, as can be expected, at the turning points of the business cycle. This can probably be explained by the unique circumstances which prevailed at the time of the turning points and which also differ from turning point to turning point.

There were also other instances where the model failed to accurately capture changes in inventory investment. These seem to occur during periods of unusual economic conditions. One such example is the Southeast-Asian financial crisis during the period 1996 to 1998 (South African Reserve Bank, Annual Economic Report, 1998 and 1999). The model underestimated the pace of inventory accumulation during 1999 when economic activity recovered considerably faster than anticipated.

The fact that the model cannot predict adverse movements in inventory investment at the turning points of the business cycle and during unusual economic conditions could probably be attributed to unplanned inventory investment. The goodness of fit statistics and diagnostic tests indicate that the predicted values of the model give a good indication of expected inventory investment under normal macroeconomic conditions. Consequently, unplanned inventory investment can be calculated as the difference between the predicted and the actual values of inventory investment. 


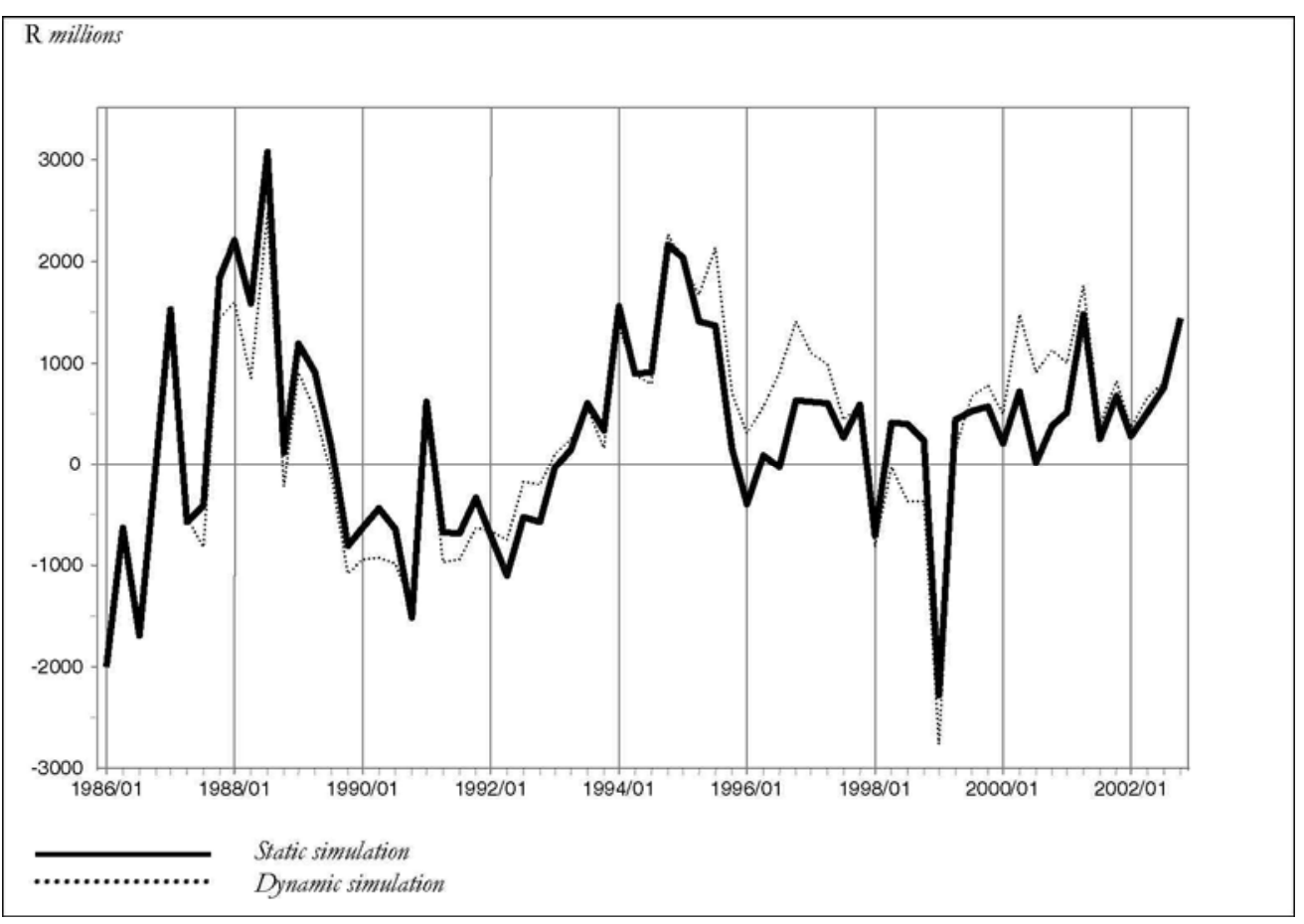

Figure 2. Real industrial and commercial inventory investment: Fitted values

The results of the model indicate that actual sales, production, unfilled orders, price levels, interest rates and expected sales have an influence on the evolution of inventory investment. These variables are directly or indirectly influenced by macroeconomic policy decisions and through their influence on inventory investment it also influences changes in gross domestic product. Therefore, prior information on the factors that influence inventory investment contributes to explaining changes in gross domestic product and may help to prepare more accurate short-term forecasts of overall economic activity.

\section{THE CONTRIBUTION OF INVENTORY INVESTMENT TO THE GROWTH IN GROSS DOMESTIC PRODUCT}

The influence of inventory investment and the indirect influence of interest rates and unplanned inventory investment on the growth in gross domestic product are evaluated in this section. The time period under review is from the first quarter of 1997 to the first quarter of 2000. This is a period of unusual macroeconomic activity during and after the Southeast-Asian financial crisis (South African Reserve Bank, Annual Economic Report, 1998-2001).

Real gross domestic product increased at an average annualised rate of 1,1 per cent from the first quarter of 1997 to the first quarter of 1999 (hereafter called the downswing period). Economic growth then accelerated sharply to an average annualised rate of 3,2 per cent from the first quarter of 1999 to the first quarter of 2000 (hereafter called the upswing period). During these periods inventory investment has also shown sharp 
openUP (August 2007)

Table 4. Contribution to the growth in gross domestic product

\begin{tabular}{|c|c|c|}
\hline & 1997:01-1999:01 & 1999:01-2000:01 \\
\hline $\begin{array}{l}\text { Gross domestic product* } \\
\text { Contribution to the } \\
\text { gross domestic product }\end{array}$ & 1.1 & 3.2 \\
\hline Inventory investment & -0.9 & 3.4 \\
\hline Expected inventory & -1.3 & 2.2 \\
\hline Unplanned inventory & 0.4 & 1.2 \\
\hline $\begin{array}{l}\text { Expected inventory } \\
\text { with interest rate shock }\end{array}$ & & 1.8 \\
\hline
\end{tabular}

Source: South African Reserve Bank * Compounded

annualised growth

fluctuations. The level of inventories at constant 1995 prices decreased by R5,2 billion during the downswing period, but was replenished with R7,5 billion during the upswing period (South African Reserve Bank, Quarterly Bulletin, September 2003).

To assess the influence of inventory investment on the growth in gross domestic product the contribution of actual and unplanned inventory investment to growth in the gross domestic product is compared. As indicated earlier, unplanned inventory investment is the difference between actual and predicted inventory investment.

In Table 4 the contribution of inventory investment to the growth in gross domestic product is shown. It is calculated by the ratio of the difference between the end value and the starting value of inventory investment, and the difference between the end and starting value of gross domestic product, multiplied by the growth in gross domestic product over the period. Actual inventory investment subtracted 0,9 percentage points from economic growth in the downswing period. In the upswing period it contributed 3,4 percentage points to the growth in gross domestic product.

The contribution of unplanned inventory investment during the period under review was also more significant during the upswing than the downswing period. Unplanned inventory investment contributed 0,4 percentage points during the downswing period and 1,2 percentage points during the upswing period to the growth in gross domestic product. This means that unplanned inventory investment increased the contribution of expected inventory investment to growth in the gross domestic product by more than a third during the downswing period and by almost 50 per cent during the upswing period.

A number of factors could have contributed to the unplanned inventory investment. The Annual Economic Report of the South African Reserve Bank (1998-2001) reports extensively about the imbalance between supply and demand during the period under review. During the downswing period the growth in production receded at a slower pace than demand, and provision was made for higher than the actual demand during the upswing period. In addition, the ratio of inventories to sales declined during the downswing period and firms tried to restore the inventory to sales ratio during the upswing period.

Together with the imbalance between supply and demand, interest rates were also very volatile during this period. In an effort to restore financial stability during 1998, bank lending rates were increased from about 20,3 per cent in the first quarter of 1997 to 24,5 per cent at the end of 1998. During 1999 interest rates were lowered sharply to reach 14,7 per cent in the first quarter of 2000. 
As interest rates have a significant influence on inventory investment, a dynamic simulation of the model was performed to assess the contribution of the reduction in interest rates during 1999 to inventory investment and its subsequent contribution to growth in the gross domestic product. For this simulation the interest variable was kept unchanged at 24,5 per cent from the fourth quarter of 1998 onwards. In accordance with the motives to hold inventories it is expected that an increase in the holding cost of inventories will lead to a reduction in inventory levels.

The results of the simulation show that the reduction in interest rates during 1999 increased the contribution of planned inventory investment to the growth in gross domestic product by about 0,4 percentage points. Although it seems to be insignificant, it should be taken into account that the upswing period lasted only four quarters and that the interest rate variable affects inventory investment with a lag of two quarters. Fig. 3 shows the influence of the lowering of interest rates during 1999.

In addition, the duration of the influence of interest rates on inventory investment lasted about eight quarters. This means that the weaker pace of actual inventory investment during the second half of 2000 and the first half of 2001 could have been worse if interest rates were not lowered during 1999.

\section{CONCLUSION}

This study has found that, although the behaviour of inventory investment in South Africa is broadly similar to that in developed countries, there is a distinct difference. The variance of sales exceeds the variance of production and there is a negative correlation between inventory investment and sales. This contrast to developed countries has also been found in other developing countries and can be ascribed to the influence of demand shocks on inventory investment. On this basis the production-smoothing hypothesis is accepted as relevant to describe inventory investment in South Africa. The features of inventory investment were therefore investigated with an inventory adjustment model.

The model describes how the level of inventories adjusts when it deviates from the desired level. The desired inventory level is a function of the ratio between inventories and sales, which can change during the business cycle. The link between sales with production, prices, unfilled orders and interest rates has an influence on this ratio. In addition, the model describes the adjustment of inventories when actual sales deviate from expected sales.

The results of the model confirm that actual sales, production, unfilled orders, the level of prices, current interest rates and expected sales have an influence on the evolution of inventory investment. Of significant importance is the ability to identify unplanned inventory investment and the finding that interest rates have a negative impact on inventory investment.

Although the model cannot predict sharp movements in inventory investment, it delivers an important contribution to the understanding of the behaviour of inventory investment in South Africa. A better knowledge of the character of inventory investment and the factors that influence it should improve the analyses of short-term changes in macroeconomic conditions and contribute to improving economic policy formulation. 
openUP (August 2007)

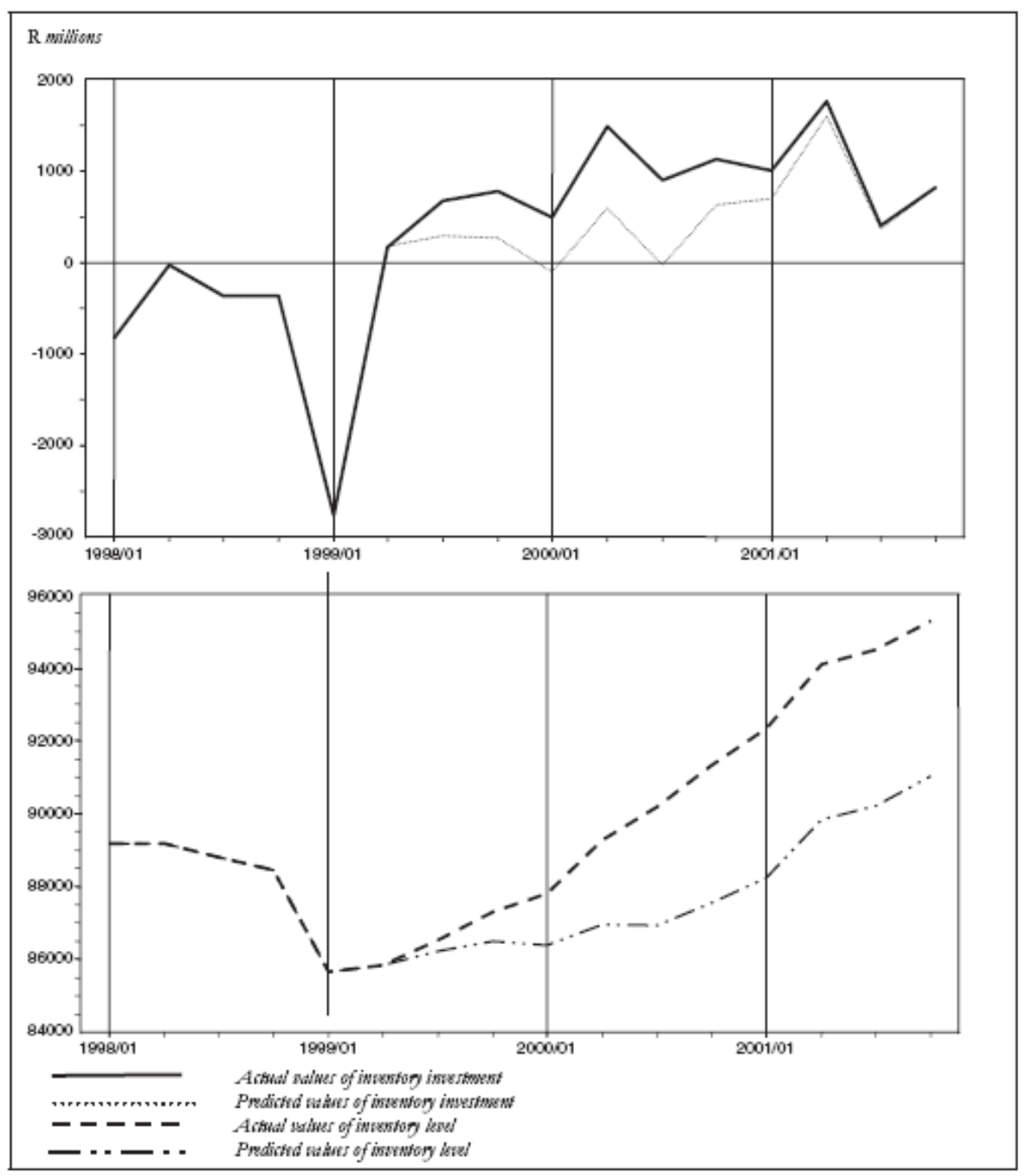

Figure 3. The influence of no change in the level of interest rates from the fourth quarter of 1998 


\section{REFERENCES}

BLANCHARD, O. J. (1983). The production and inventory behavior of the American automobile industry. Journal of Political Economy, 91, 265-400.

BLINDER, A. S. (1986). Can the production smoothing model of inventories be saved? Quarterly Journal of Economics, CI, 431-454.

BLINDER, A. S. and MACCINI, C. J. (1991). Taking stock: A critical assessment of recent research on inventories. Journal of Economic Perspective, vol. 5, No. 1, 73-96. ENGLE, R. F. and GRANGER, C. W. J. (1987). Co-integration and error correction: Representation, Estimation and Testing, Econometrica, vol. 55, 251-276.

ENGLE, R. F. and YOO, S. B. (1987). Forecasting and testing in co-integrated systems, Journal of Econometrics, vol. 35, 143-159.

FELDSTEIN, M. S. and AUERBACH, A. J. (1976). Inventory behavior in durable goods manufacturing: The target adjustment model, Brookings papers on economic activity, 351-396 FLOOD, D. and LOWE, P. (1993). Inventories and the business cycle. Reserve Bank of Australia, Research Discussion Paper, No. 9306.

FLOOD, D. and LOWE, P. (1995). Inventories and the business cycle. The Economic Record, vol. 71, No. 212, 27-39.

FUKUDA, S. and TERUYAMA, H. (1988). Some international evidence on inventory fluctuations. Economics Letters, No. 8, 225-230.

GUARIGLIA, A. and SCHIANTARELLI, F. (1998). Production smoothing, firms' heterogeneity, and financial constraints: evidence from a panel of UK firms. Oxford economic papers September, No. 50, 63-78.

HOLT, C. C., MODIGLIANI, F., MUTH, J. and SIMON, H. (1960). Planning production, inventories and workforce. Englewood Cliffs, N.J.: Prentice-hall.

KAHN, J. A. and McConnell, M. M. (2002). Has inventory volatility returned? Current issues in economics and finance, Federal Reserve Bank of New York, vol. 8, No. 5 May.

LOVELL, M. (1961). Manufacturers' inventories, sales, expectations, and the accelerator principle. Econometrica, vol. 29, No. 3, July, 293-314.

MILNE, A. (1994). The production smoothing model of inventories revisited. Economic Journal, 104, 399-407.

RAMEY, V. A. and WEST, K. D. (1997). Inventories. National Bureau of Economic Research, Working Paper, No. 6315.

SHRESTHA, M. and FASSLER, S. (2003). Changes in inventories in the national accounts. International Monetary Fund, Working Paper, No. WP/03/120.

SMALL, IAN. (2000). Inventory investment and cash flow. Bank of England, Working Paper, No. 112.

SMITH, H. (2004). 'n Ontleding van voorraadinvestering in Suid-Afrika. D. Com. Tesis, Universiteit van Pretoria: Pretoria.

SMITH, H. and VAN DEN HEEVER, J. P. (1995). Inventory investment in South Africa. South African Reserve Bank, Quarterly bulletin, September.

SOUTH AFRICAN RESERVE BANK, Annual economic report, various editions. SOUTH AFRICAN RESERVE BANK, Quarterly bulletin, various editions. 